\title{
Clinical significance of intraperitoneal CD44 mRNA levels of magnetically separated CD45-negative EpCAM-positive cells for peritoneal recurrence and prognosis in stage II and III gastric cancer patients
}

MASAHIRO HORIKAWA, HISAE IINUMA, TAISUKE INOUE, ETUSHI OGAWA and RYOJI FUKUSHIMA

Department of Surgery, Teikyo University School of Medicine, Tokyo 173-0003, Japan

Received October 15, 2010; Accepted November 8, 2010

DOI: 10.3892/or.2011.1191

\begin{abstract}
Peritoneal recurrence of gastric cancer patients is a serious problem. Recently, the CD44 molecule was reported to be a marker of cancer stem cells in gastric cancer. In this study, we examined the prognostic significance of CD44 mRNA levels in magnetically separated CD45-negative EpCAM-positive (CD45-EpCAM ${ }^{+}$) cells, in the peritoneal washes collected from gastric cancer patients with TNM stage II and III. A total of 147 gastric cancer patients with stage II $(n=75)$ and III $(n=72)$ were included. All patients were negative by peritoneal cytology. Peritoneal washes of the Douglas pouch were collected and used for pathological cytology and molecular diagnosis. Prior to molecular diagnosis, $\mathrm{CD} 45-\mathrm{EpCAM}^{+}$cells were separated from peritoneal washings by an auto-magnetic-activated cell separation system. CD44 and CEA mRNA levels of the CD45-EpCAM ${ }^{+}$fraction were detected by real-time RT-PCR. The CD44 mRNA and CEA mRNA levels in the peritoneal washes showed a significant correlation with tumor size and stage. In patients with stage III, peritoneal recurrence-free survival rates (PRFS) and overall survival rates (OS) of CD44 $\mathrm{mRNA}^{+}$or CEA mRNA ${ }^{+}$ patients were significantly worse than those of marker genenegative patients. In stage II patients, PRFS and OS of CD44 $\mathrm{mRNA}^{+}$patients were significantly worse than those of marker gene-negative patients. In the Cox regression hazard model analysis, the presence of CD44 mRNA in peritoneal washes was found to be an independent prognostic factor for PRFS
\end{abstract}

Correspondence to: Dr Hisae Iinuma, Department of Surgery, Teikyo University School of Medicine, 2-11-1 Kaga, Itabashi-ku, Tokyo 173-0003, Japan

E-mail: iinuma@med.teikyo-u.ac.jp

Abbreviations: RT-PCR, reverse transcription-polymerase chain reaction; CEA, carcinoembryonic antigen; GAPDH, glyceraldehyde3-phosphate-dehydrogenase

Key words: gastric cancer, peritoneal recurrence, cancer stem cell, free cancer cells, real-time reverse transcriptase-polymerase chain reaction, peritoneal washing, CD44, carcinoembryonic antigen and OS in stage II and III. In contrast, CEA mRNA levels of these samples showed a prognostic value only in stage III. Our results suggest that CD44 mRNA of magnetically separated $\mathrm{CD} 45-\mathrm{EpCAM}^{+}$cell fraction of peritoneal washes is a useful genetic marker for predicting high-risk individuals among gastric cancer patients with stage II and III.

\section{Introduction}

Gastric cancer still remains the most common cancer in Japan (1). Peritoneal recurrence is the most frequent event in gastric cancer patients, and it is known that the prognosis of these patients is poor $(2,3)$. Peritoneal recurrence presumably arises from the intraperitoneal seeding of cancer cells, and the presence of free cancer cells in the peritoneal fluid is an early event in peritoneal seeding (4-6). In gastric cancer, positive intraperitoneal washes cytology $\left(\mathrm{cy}^{+}\right)$is regarded as distant metastasis (M1), and $\mathrm{cy}^{+}$patients are classified as stage IV in the International Union Against Cancer (UICC)-TNM and the Japanese Classification of Gastric Carcinoma (JCGC) $(7,8)$. However, peritoneal recurrence sometimes occurs in TNM stage II and III patients because of the low sensitivity of conventional pathological cytology techniques (9). Therefore, more highly sensitive methods based on the reverse transcriptase-polymerase chain reaction (RT-PCR) are of interest. The clinical significance of detecting free cancer cells using genetic markers such as tumor-associated antigens [carcinoembryonic antigen (CEA)] or epithelial cell antigens [cytokeratin 20 (CK20)] (10-13) has been reported. However, only few reports have been published concerning the significance of these genetic markers in each staging of gastric cancer patients.

Recently, the new concept of cancer stem cells has focused on trying to devise novel diagnostic and therapeutic procedures (14). Cancer stem cells have been defined as a unique subpopulation in tumors that possess the ability to initiate tumor growth and sustain tumor self-renewal (15-17). Accumulating evidence shows that cancer stem cells are associated with metastasis, resistance to chemotherapy and radiotherapy, and recurrence. Regarding the marker expression of cancer stem cells, some cancer specific expression patterns exist. Although there are some discrepancies, most 
cancer stem cells express $\mathrm{CD} 44^{+} \mathrm{CD} 24-/ \mathrm{lowESA}^{+}$in breast cancer, $\mathrm{CD}_{133^{+}}$and $\mathrm{EpCAM}^{\mathrm{high}} \mathrm{CD} 44^{+}\left(\mathrm{CD} 166^{+}\right)$in colon cancer, $\mathrm{CD} 133^{+}$in brain cancer, and $\mathrm{CD} 44^{+} \mathrm{CD} 24^{+} \mathrm{ESA}^{+}$or $\mathrm{CD} 33^{+}$in pancreatic cancer (18-22). Recently, Takaishi et al defined the existence of gastric cancer initiating cells in the $\mathrm{CD} 44^{+}$population of gastric cancer cell lines (23). Other publications have suggested that CD44 may be more specific markers for stem cells (24). However, it is known that CD44 is expressed not only in cancer stem cells but also in a variety of cells include the blood cells. Therefore, for the detection of CD44 originated in cancer stem cells in peritoneal washes, deletion of $\mathrm{CD} 44^{+}$blood cells from peritoneal washes is essential.

In this study, we evaluated the usefulness of CD44 mRNA in peritoneal washes for predicting peritoneal recurrence and prognosis in gastric cancer with TNM stage II and III. Especially, we separated the CD45-negative and EpCAMpositive cell fractions $\left(\mathrm{CD} 45-\mathrm{EpCAM}^{+}\right)$from peritoneal washes by the Auto-MACS in order to detect the CD44 mRNA originated in cancer cells.

\section{Patients and methods}

Subjects and study design. A total of 147 gastric cancer patients with stage II $(n=75)$ or III $(n=72)$ were studied. The patients were patological cytology negative. This study was a retrospective analysis of clinical outcome coupled with analysis of stored cells separated from peritoneal washings. The samples of peritoneal washes were collected from 2000 to 2006. Conventional pathological cytology of peritoneal washes was negative in all patients. Tumors were staged according to the TNM classification and the categories were determined from pathological findings based on surgically resected specimens $(7,8)$. The median follow-up period was 37 months (range, 7-68 months). This study was approved by the institutional review board of Teikyo University Hospital, and all patients provided written informed consent.

Peritoneal washes and magnetic cell separation. Peritoneal washes collected from gastric cancer patients and 20 patients with benign disease (gallstone patients) were prepared. At the beginning of each operation, $100 \mathrm{ml}$ saline was introduced into the Douglas pouch and aspirated after gentle stirring. One half of each wash was used for cytopathology and the other half was used for the genetic examination. For the genetic examination, cancer-enriched cells were separated from peritoneal washes by two-steps Auto-MACS system. First, blood cells were removed by negative selection using the anti-CD45 mouse mAb-conjugated microbeads (CD45 microbeads), and then cancer cells were enriched by positive selection using the anti-EpCAM mouse MAb-conjugated microbeads (EpCAM microbeads) described previously $(25,26)$. Finally, $\left(\mathrm{CD} 45-\mathrm{EpCAM}^{+}\right)$were collected and stored at $-80^{\circ} \mathrm{C}$ for RNA extraction procedure.

Quantitative real-time RT-PCR. Total RNA of samples was extracted using a guanidinium-isothiocyanate-phenolchloroform-based method using TRIzol (Invitrogen, Carlsbad, CA). One-step real-time quantitative RT-PCR for CD44, CEA and GAPDH mRNA was performed using a LightCycler instrument (Roche Diagnostics, Mannheim, Germany). The sequences of the primers and probes for CEA and GAPDH, and the PCR conditions have been described previously (12). The primers and probe for CD44 mRNA were as follows: sense, 5'-TCCAGGCAACTCCTAGTAGTA-3'; antisense, 5'-CTGTCCCTGTTGTCGAAT-3'; and probes, 5'-AAACAG CTACCCGAGAGGAACAGTGGTTTGG-3'-fluorescein (donor) and 5'-LCRed640-AACAGATGGCATGAGGGATA TCGCCAAACAC-3'-phosphorylated (acceptor). For amplification of $\mathrm{CD} 44$, initial denaturation at $95^{\circ} \mathrm{C}$ for $10 \mathrm{~min}$ was followed by $20 \mathrm{sec}$ at $95^{\circ} \mathrm{C}, 20 \mathrm{sec}$ at $60^{\circ} \mathrm{C}$ and $20 \mathrm{sec}$ at $72^{\circ} \mathrm{C}$. All samples were measured in duplicate. As an external standard, the PCR product of each target gene was cloned into a TOPO TA cloning plasmid vector (Invitrogen). The mRNA in each sample was quantified automatically with reference to the standard curve of the plasmid, using LightCycler software. The levels of CEA and CD44 mRNA were normalized to GAPDH, and the ratios of the CEA and CD44 copy numbers to the GAPDH copy numbers (CEA/GAPDH and CD44/ GAPDH) were calculated. The cut-off values for CEA/ GAPDH and CD44/GAPDH were determined as the 95\% confidence intervals (mean plus 1.96 standard deviation) of the peritoneal washes from 20 patients with benign disease.

Postoperative surveillance. The follow-up program, which consisted of interim history, physical examination, hematology and blood chemistry, was performed every 3 months for the first operative year and every 6 months thereafter. Computed tomography or abdominal ultrasonography was examined every 6 months. Evidence of peritoneal recurrence was diagnosed comprehensively using various methods, including paracentesis and autopsy.

Statistical analysis. The sample size of this study was determined by use of SAS v9.2 software (SAS Institute, Inc., Tokyo). Peritoneal recurrence-fee survival (PRFS) was analyzed using the Kaplan-Meier method, with death and a clinical diagnosis of peritoneal recurrence as end-points. Overall survival (OS) was analyzed with death as end-points. P-values are estimated by log-rank tests. Univariate and multivariate analysis were performed using Cox regression hazard model analysis. $\mathrm{P}<0.05$ was considered significant. Data were analyzed using JMP 7.0 software (SAS Institute, Inc.).

\section{Results}

Cut-off levels for CEA and CD44 mRNA. To determine the cut-off values for CEA/GAPDH and CD44/GAPDH, we examined the peritoneal washes of benign disease patients. As cut-off values, we determined 0.14 for CEA/GAPDH and 0.76 for CD44/GAPDH to be the $95 \%$ confidence interval (mean plus 1.96 standard deviation) (data not shown).

Positive rates and the sensitivity and specificity of genetic markers. The PCR positive rates of CEA mRNA, CD44 mRNA were examined in all patients $(\mathrm{n}=147)$, and the results are shown in Table I. The positive rates of CEA (33.33\%) were higher than that of CD44 (27.89\%). The peritoneal recurrence rates of patients with stage II or III were $12 \%(9 / 75)$ and $27.78 \%$ (20/72), respectively. Next, we examined the sensi- 
Table I. Comparison of positive rates and the sensitivities and specificities of CD44 and CEA mRNA for peritoneal recurrence.

\begin{tabular}{lccc}
\hline $\begin{array}{l}\text { Genetic } \\
\text { markers }\end{array}$ & $\begin{array}{l}\text { Positive } \\
\text { rate (\%) }\end{array}$ & Sensitivity (\%) & Specificity (\%) \\
\hline $\mathrm{CD} 44^{+}$ & $27.89(41 / 147)$ & $51.72(15 / 29)$ & $77.97(92 / 118)$ \\
$\mathrm{CEA}^{+}$ & $33.33(49 / 147)$ & $55.17(16 / 29)$ & $72.03(85 / 118)$ \\
\hline
\end{tabular}

The positive rates of each genetic marker, and the sensitivities and specificities for peritoneal recurrence were examined in $\mathrm{CEA}^{+}$and CD44+ groups.

Table II. Relationships between clinicopathological factors and CD44 mRNA positivity rates.

\begin{tabular}{lcccc}
\hline & $\begin{array}{c}\text { No. of } \\
\text { patients }\end{array}$ & $\begin{array}{c}\text { CD44 } \\
\text { positive }\end{array}$ & Positivity & \\
Variables & $(\mathrm{n}=147)$ & cases $(\mathrm{n}=41)$ & rates (\%) & P-value \\
\hline
\end{tabular}

\begin{tabular}{lcccc}
\hline Age (years) & $66 \pm 11$ & & & \\
Gender & & & & \\
Male & 97 & 28 & 28.87 & 0.714 \\
Female & 50 & 13 & 26.00 &
\end{tabular}

Tumor size $(\mathrm{cm})$

$\begin{array}{lrrrr}<5 & 35 & 5 & 14.29 & 0.039^{\mathrm{a}} \\ \geq 5 & 112 & 36 & 32.14 & \end{array}$

Histological

type

$\begin{array}{rrrr}\text { G1 } & 17 & 5 & 29.41 \\ >\mathrm{G} 2 & 130 & 36 & 27.69\end{array}$

Depth of

invasion

pT1

$>$ pT2

7

0

0.00

29.29

Lymphatic

invasion

L0

Venous invasion

$$
\text { V0 }
$$$$
\text { V1 }
$$

$\begin{array}{rr}30 & 6 \\ 117 & 35\end{array}$

20.00

29.91

0.361

Lymph node

metastasis

$\begin{array}{rrrr}\text { pN0 } & 7 & 0 & 0.00 \\ >\text { pN1 } & 140 & 41 & 29.29\end{array}$

0.191

TNM stage

\begin{tabular}{lllll} 
II & 75 & 10 & 13.33 & $<0.001^{\mathrm{a}}$ \\
III & 72 & 31 & 43.06 & \\
\hline
\end{tabular}

Table III. Relationships between clinicopathological factors and CEA mRNA positivity rates.

\begin{tabular}{|c|c|c|c|c|}
\hline Variables & $\begin{array}{l}\text { No. of } \\
\text { patients } \\
(n=147)\end{array}$ & $\begin{array}{c}\text { CEA } \\
\text { positive } \\
\text { cases }(n=49)\end{array}$ & $\begin{array}{l}\text { Positivity } \\
\text { rates }(\%)\end{array}$ & P-value \\
\hline Age (years) & $66 \pm 11$ & & & \\
\hline \multicolumn{5}{|l|}{ Gender } \\
\hline Male & 97 & 36 & 37.11 & 0.178 \\
\hline Female & 50 & 13 & 26.00 & \\
\hline \multicolumn{5}{|c|}{ Tumor size (cm) } \\
\hline$<5$ & 35 & 6 & 17.14 & $0.024^{\mathrm{a}}$ \\
\hline$\geq 5$ & 112 & 43 & 38.39 & \\
\hline \multicolumn{5}{|l|}{$\begin{array}{l}\text { Histological } \\
\text { type }\end{array}$} \\
\hline G1 & 17 & 7 & 41.18 & 0.585 \\
\hline$>\mathrm{G} 2$ & 130 & 42 & 32.31 & \\
\hline \multicolumn{5}{|l|}{$\begin{array}{l}\text { Depth of } \\
\text { invasion }\end{array}$} \\
\hline pT1 & 7 & 1 & 14.29 & 0.425 \\
\hline$>$ pT2 & 140 & 48 & 34.29 & \\
\hline \multicolumn{5}{|l|}{$\begin{array}{l}\text { Lymphatic } \\
\text { invasion }\end{array}$} \\
\hline L0 & 30 & 7 & 23.33 & 0.278 \\
\hline L1 & 117 & 42 & 35.90 & \\
\hline \multicolumn{5}{|c|}{ Venous invasion } \\
\hline V0 & 34 & 12 & 35.29 & 0.837 \\
\hline V1 & 113 & 37 & 32.74 & \\
\hline \multicolumn{5}{|l|}{$\begin{array}{l}\text { Lymph node } \\
\text { metastasis }\end{array}$} \\
\hline pNO & 7 & 1 & 14.29 & 0.425 \\
\hline$>\mathrm{pN} 1$ & 140 & 48 & 34.29 & \\
\hline \multicolumn{5}{|l|}{ TNM stage } \\
\hline II & 75 & 19 & 25.33 & $0.036^{\mathrm{a}}$ \\
\hline III & 72 & 30 & 41.67 & \\
\hline
\end{tabular}

tivity and specificity for peritoneal recurrence of CD44 and CEA (Table I). The CD44 group showed a higher specificity (77.97\%) and lower sensitivity (51.72\%) than those of CEA group (specificity $72.03 \%$, sensitivity $55.17 \%$ ).

Relationships between clinicopathological factors and genetic markers. Tables II and III show the relationships between the CD44 mRNA or CEA mRNA expression (in CD45-EpCAM ${ }^{+}$ cells fractions) in peritoneal washes and clinicopathological factors. Significant relationships were demonstrated between positivity for CD44 expression and tumor size and tumor stage (Table II). The positivity for CD44 mRNA did not show any significant relationships with histological type, depth of invasion, lymphatic invasion, venous invasion and lymph 


\section{A. PRFS of CD44 mRNA}

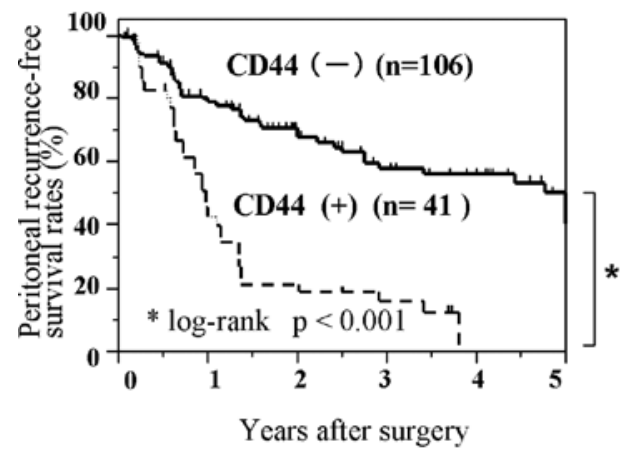

C. OS of CD44 mRNA



B. PRFS of CEA mRNA

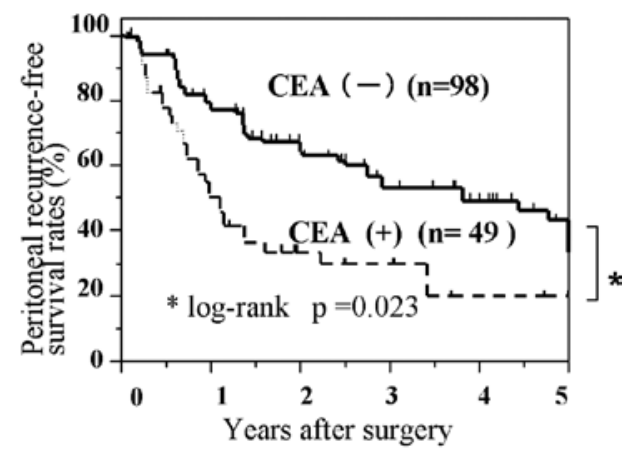

D. OS of CEA mRNA

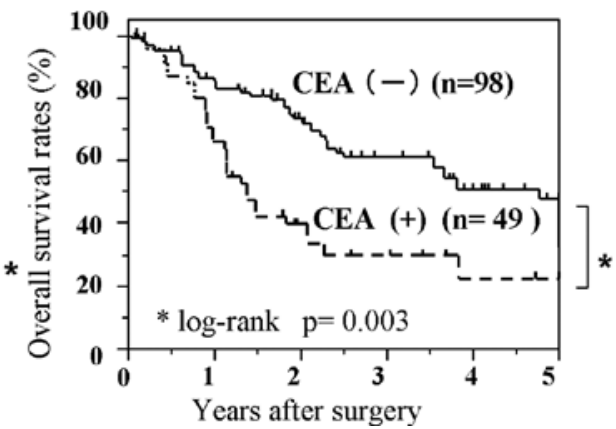

Figure 1. PRFS and OS stratified according to the results of CD44 or CEA in all patients. PRFS and OS for the patients with stage II and III (n=147) were classified based on CD44 mRNA (A, C) and CEA mRNA (B, D) and analyzed by the Kaplan-Meier method. Significant differences exist between the CD44positive and negative groups, and CEA-positive and negative groups.

\section{A. PRFS of CD44 mRNA}

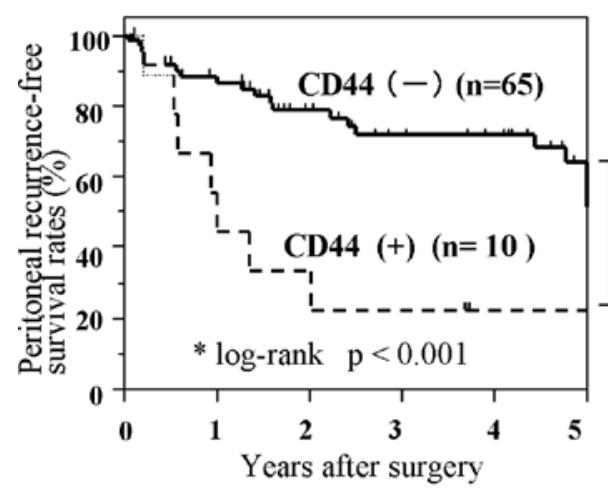

C. OS of CD44 mRNA

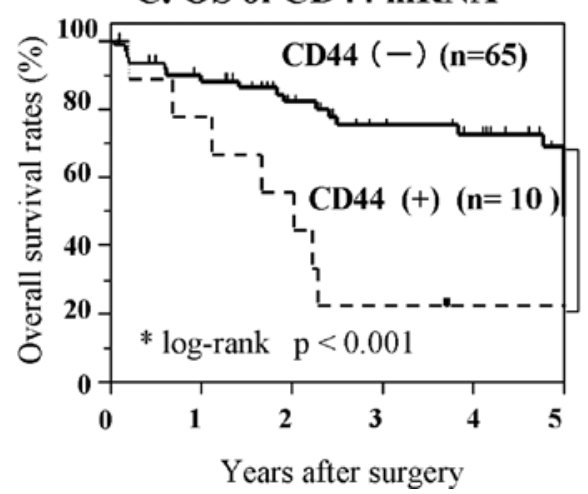

B. PRFS of CEA mRNA

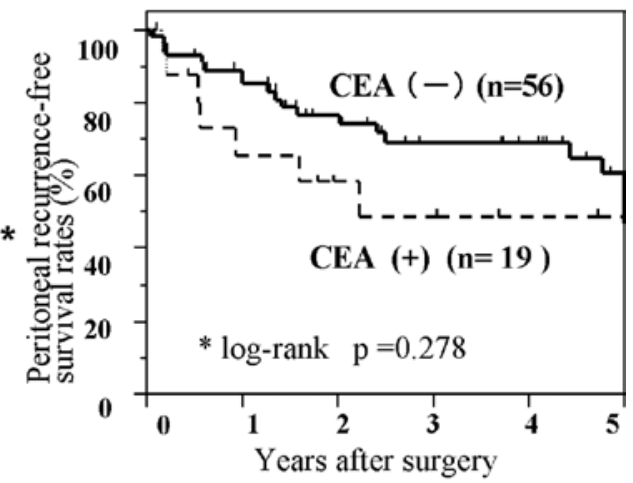

D. OS of CEA mRNA

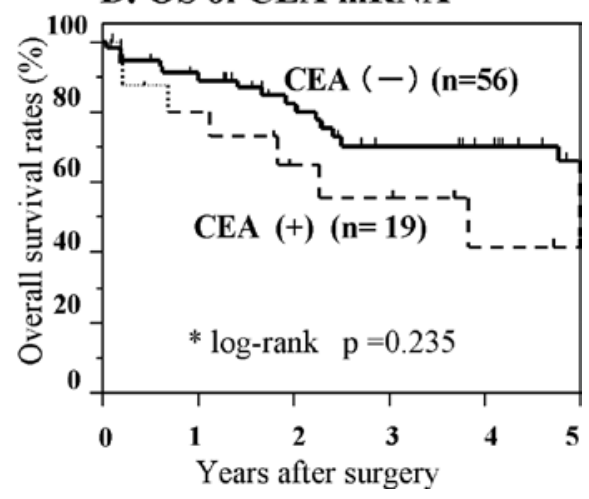

Figure 2. PRFS and OS stratified according to the results of CD44 or CEA in stage II patients. PRFS and OS of the stage II patients (n=75) were classified based on CD44 mRNA (A, C) and CEA mRNA (B, D) and analyzed by the Kaplan-Meier method. Significant differences exist between the CD44 mRNApositive and negative groups. 


\section{A. PRFS of CD44 mRNA}

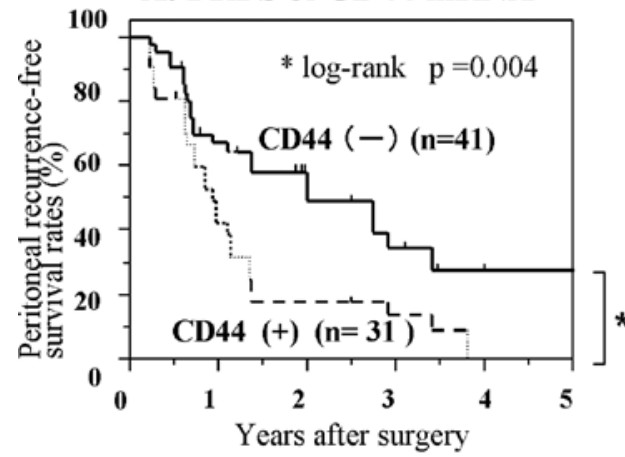

C. OS of CD44 mRNA

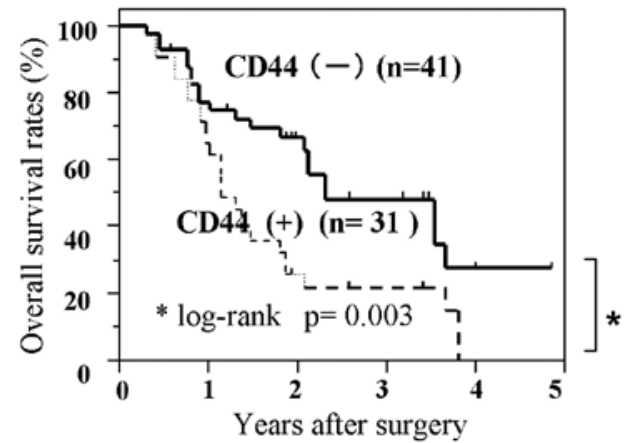

\section{B. PRFS of CEA mRNA}

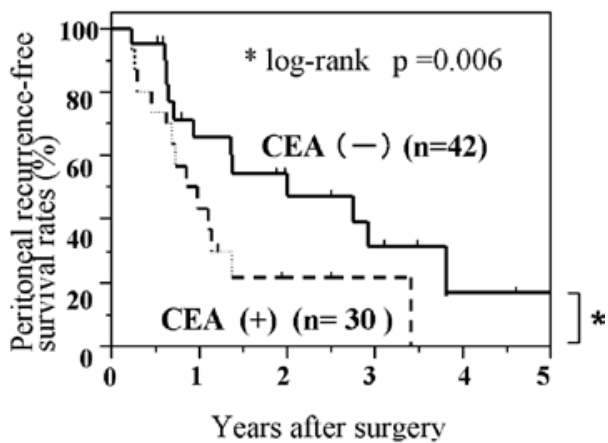

D. OS of CEA mRNA

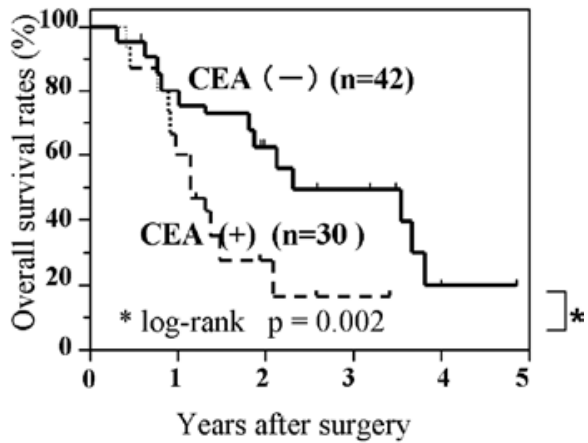

Figure 3. PRFS and OS stratified according to the results of CD44 or CEA in stage III patients. PRFS and OS for the patients with stage III (n=72) were classified based on CD44 mRNA (A, C) and CEA mRNA (B, D) and analyzed by the Kaplan-Meier method. Significant differences exist between the CD44 mRNA-positive and negative groups, and CEA mRNA-positive and negative groups.

Table IV. Multivariate analysis of prognostic factors for PRFS and OS in all patients.

\begin{tabular}{|c|c|c|c|c|c|c|}
\hline & \multicolumn{3}{|c|}{ Peritoneal recurrence-free survival } & \multicolumn{3}{|c|}{ Overall survival } \\
\hline & $\mathrm{RC}^{\mathrm{a}}$ & $\mathrm{HR}^{\mathrm{b}}$ & P-value & $\mathrm{RC}$ & HR & P-value \\
\hline CD44 mRNA & -0.91 & $0.40(0.24-0.66)$ & $0.001^{\mathrm{c}}$ & -9.45 & $0.39(0.23-0.65)$ & $0.001^{\mathrm{c}}$ \\
\hline Tumor size & 0.28 & $1.33(0.73-2.53)$ & 0.359 & 0.27 & $1.31(0.72-2.52)$ & 0.386 \\
\hline Lymph node metastasis & 1.65 & $5.19(1.08-93.11)$ & $0.037^{\mathrm{c}}$ & 1.61 & $5.02(1.05-90.08)$ & $0.042^{\mathrm{c}}$ \\
\hline TNM stage & 0.69 & $2.00(1.17-3.52)$ & $0.011^{\mathrm{c}}$ & 0.67 & $1.95(1.14-3.44)$ & $0.015^{\mathrm{c}}$ \\
\hline CEA mRNA & -0.57 & $0.57(0.35-0.92)$ & $0.022^{\mathrm{c}}$ & -0.65 & $0.52(0.32-0.86)$ & $0.011^{\mathrm{c}}$ \\
\hline Tumor size & 0.17 & $1.19(0.66-1.56)$ & 0.465 & 0.15 & $1.17(0.66-1.51)$ & 0.495 \\
\hline Lymph node metastasis & 1.65 & $5.22(1.09-93.67)$ & $0.037^{\mathrm{c}}$ & 1.60 & $4.97(1.04-89.18)$ & $0.044^{c}$ \\
\hline TNM stage & 0.88 & $2.42(1.44-4.20)$ & $0.001^{\mathrm{c}}$ & 0.86 & $2.37(1.40-4.13)$ & $0.001^{\mathrm{c}}$ \\
\hline
\end{tabular}

${ }^{\mathrm{a} C}$, regression coefficient. ${ }^{\mathrm{b}} \mathrm{HR}$, Hazard ratio (95\% confidence interval).

node metastasis. Significant relationships were demonstrated between positivity for CEA mRNA expression and tumor size and tumor stage (Table III). The positivity for CEA mRNA did not show any significant relationships with histological type, depth of invasion, lymphatic invasion, venous invasion and lymph node metastasis.

Correlation between genetic markers and survival. KaplanMeier peritoneal recurrence-free survival (PRFS) curves and overall survival (OS) curves were compared according to the expression status of CD44 mRNA or CEA mRNA in all patients (Fig. 1). In this analysis, the $\mathrm{CD}_{4} 4^{+}$group showed significantly worse PRFS and OS than those of the CD44- group $\left(\mathrm{P}<0.001\right.$ in PRFS and OS). The $\mathrm{CEA}^{+}$group also showed significantly worse PRFS and OS than those of the $\mathrm{CEA}^{-}$group $(\mathrm{P}=0.023$ in $\mathrm{PRFS}, \mathrm{P}=0.003$ in OS$)$. Next, we examined the PRFS and OS at each stage according to the PCR status (Figs. 2 and 3). In stage II, the PRFS and OS of the $\mathrm{CD}_{4} 4^{+}$groups were significantly worse than those of CD44- groups ( $\mathrm{P}<0.001$ in PRFS and OS) (Fig. 2). In contrast, 
Table V. Multivariate analysis of prognostic factors for PRFS and OS in stage II patients.

\begin{tabular}{|c|c|c|c|c|c|c|}
\hline & \multicolumn{3}{|c|}{ Peritoneal recurrence-free survival } & \multicolumn{3}{|c|}{ Overall survival } \\
\hline & $\mathrm{RC}^{\mathrm{a}}$ & $\mathrm{HR}^{\mathrm{b}}$ & P-value & $\mathrm{RC}$ & HR & P-value \\
\hline CD44mRNA & -1.37 & $0.25(0.11-0.67)$ & $0.008^{\mathrm{c}}$ & -1.36 & $0.26(0.10-0.69)$ & $0.009^{\mathrm{c}}$ \\
\hline Lymph node metastasis & 1.37 & $3.93(0.80-71.01)$ & 0.102 & 1.39 & $4.01(0.82-72.16)$ & 0.095 \\
\hline CEA mRNA & -0.33 & $0.72(0.31-1.84)$ & 0.464 & -0.37 & $0.69(0.30-1.77)$ & 0.416 \\
\hline Lymph node metastasis & 1.46 & $4.29(0.88-77.53)$ & 0.077 & 1.47 & $4.35(0.89-78.25$ & 0.073 \\
\hline
\end{tabular}

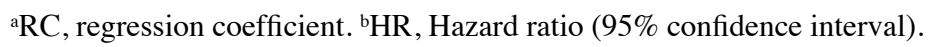

Table VI. Multivariate analysis of prognostic factors for PRFS and OS in stage III patients.

\begin{tabular}{|c|c|c|c|c|c|c|}
\hline & \multicolumn{3}{|c|}{ Peritoneal recurrence-free survival } & \multicolumn{3}{|c|}{ Overall survival } \\
\hline & $\mathrm{RC}^{\mathrm{a}}$ & $\mathrm{HR}^{\mathrm{b}}$ & P-value & $\mathrm{RC}$ & HR & P-value \\
\hline CD44 mRNA & -0.74 & $0.48(0.27-0.85)$ & $0.011^{\mathrm{c}}$ & -0.77 & $0.46(0.26-0.82)$ & $0.009^{c}$ \\
\hline Histological type & -1.02 & $0.36(0.14-1.25)$ & 0.099 & -1.12 & $0.33(0.12-1.13)$ & 0.074 \\
\hline CEA mRNA & -0.73 & $0.48(0.27-0.87)$ & $0.017^{\mathrm{c}}$ & -0.90 & $0.41(0.21-0.77)$ & $0.006^{\mathrm{c}}$ \\
\hline Histological type & -1.02 & $0.38(0.12-1.15)$ & 0.107 & -1.08 & $0.34(0.13-1.18)$ & 0.084 \\
\hline
\end{tabular}

${ }^{\mathrm{R} C}$, regression coefficient. ${ }^{\mathrm{b}} \mathrm{HR}$, Hazard ratio (95\% confidence interval).

$\mathrm{CEA}^{+}$groups did not show the significant differences in PRFS and $\mathrm{OS}$ between the $\mathrm{CEA}^{-}$groups $(\mathrm{P}=0.278$ in $\mathrm{PRFS}, \mathrm{P}=0.235$ in OS). In stage III, the PRFS and PS of CD $44^{+}$group were significantly worse than those of marker-negative group $(\mathrm{P}=0.004$ in PRFS, $\mathrm{P}=0.003$ in OS). Furthermore, PRFS and $\mathrm{OS}$ of $\mathrm{CEA}^{+}$groups were significantly worse than those of CEA ${ }^{-}$groups $(\mathrm{P}=0.006$ in PRFS, $\mathrm{P}=0.002$ in OS) (Fig. 3). These results suggest that the CD44 mRNA in peritoneal washes significantly associated with PRFS and OS in stage II and III patients, and CEA mRNA are associated with PRFS and OS in stage III patients.

Cox univariate and multivariate analysis of prognostic factors. First, we analyzed the prognostic value of CD44 and CEA mRNA for all patients. Table IV shows the multivariate Cox proportional hazard regression analysis for PRFS and OS in all patients. Multivariate analyses were evaluated in factors which showed significance in univariate analyses. CD44 and CEA were analyzed in separate group. In these analyses, CD44, lymph node metastasis and tumor stage showed significance for PRFS and OS. Next, we evaluated the prognostic value of these factors in each tumor stage. In analysis of patients with stage II, CD44 mRNA showed significance for PRFS and OS ( $\mathrm{P}=0.008$ in PRFS, $\mathrm{P}=0.009$ in OS) (Table V). In contrast, CEA mRNA did not show the significance for PRFS and OS. In analysis of patients with stage III, CD44 mRNA showed significance for PRFS and OS $(\mathrm{P}=0.011$ in PRFS, $\mathrm{P}=0.009$ in OS) (Table VI). CEA mRNA also showed significance for PRFS and OS $(\mathrm{P}=0.017$ in PRFS, $\mathrm{P}=0.006$ in OS). These results suggest that the CD44 mRNA in peritoneal washes possesses independent prognostic value for PRFS and OS in stage II and III, and CEA mRNA possesses prognostic value for PRFS and OS in stage III patients.

\section{Discussion}

This study demonstrated that the CD44 mRNA levels of $\mathrm{CD}^{4}$ EpCAM $^{+}$cell fractions in peritoneal washes of gastric cancer patients with stage II and III are an independent prognostic factor for PRFS and OS.

Cancer stem cells have been characterized as a subpopulation in cancers that possess the ability to initiate tumor growth and sustain tumor self-renewal (14-17). Accumulating evidence suggests the existence of cancer stem cells in various solid tumors, and the detection of cancer stem cells is therefore important in the accurate diagnosis and effective treatment of cancer patients (18-22). Previously, we reported that the molecular detection of free cancer cells in peritoneal washes of curative colorectal cancer patients, using multimarkers including CD133 which is cancer stem-like cell marker, are useful in prognosis (23). However, the clinical significance of cancer stem-like cells in peritoneal washes of gastric cancer has not been published. Takaishi et al reported that $\mathrm{CD} 44^{+}$gastric cancer cells showed the properties of self-renewal and the ability to form differentiated progeny, consistent with the cancer stem cell phenotype (23). CD44 is 
a class I transmembrane glycoprotein, and its transcripts are subject to alternative splicing, which creates more than 10 different isoforms (24). It can act as a ligand-binding receptor for extracellular matrices and as a specialized platform for growth factors and matrix metalloproteinases, and it has been shown to be a down-regulation target of the $\mathrm{Wnt} / \beta$ catenin pathway (27). Several recent studies have suggested that CD44 may play an important role in the tumorigenicity of cancer stem cells. It was also reported that CD44 may be more specific marker for cancer stem cells as compared to other cancer stem cell markers (24). However, it is also known that CD44 is expressed not only in cancer stem cells but also in a variety of other cells, such as blood cells. Therefore, we first separated CD45-EpCAM+ cells from peritoneal washes using the Auto-MACS system, and then measured the CD44 mRNA and CEA mRNA levels. Cancer cell enrichment using the EpCAM microbeads has been reported in various cancers and applied in the CellSearch system which has been approved by FDA $(28,29)$.

In previous studies, general markers such as CEA and CK20 mRNA were used as target genes for peritoneal free cancer cells in gastric cancer. In this study, we subjected stage II and III patients with peritoneal cytology negative. In our analysis, CD44 mRNA levels showed significant relationships between the tumor size and stage, and these results are same in those of CEA. Previous studies which include the stage I-IV gastric cancer patients, had demonstrated that the significant correlation with CEA mRNA levels and tumor size, depth of invasion, lymph node metastasis, lymphatic invasion, venous invasion, peritoneal dissemination and stage (13). Concerning the prognostic value of detecting free cancer cells in peritoneal washes using the CEA mRNA, several papers have reported on the usefulness of CEA mRNA of peritoneal washes as a sensitive predictive tool for intraperitoneal recurrence in gastric cancer patients $(10,11,30,31)$. In these published studies, predictive values for peritoneal recurrence of CEA mRNA in each stage were not examined. However, the selection of high-risk patients with stage II and III is desired in order to select those who are in need of adjuvant chemotherapy. In this study, our data showed that CEA mRNA levels of peritoneal washes are predictive marker for peritoneal recurrence and prognosis in stage III patients but not stage II. In contrast, the CD44 mRNA levels of peritoneal washes are of predictive value for peritoneal recurrence and prognosis in both stage II and III patients. These results were apparent in both the Kaplan-Meier survival analysis and the Cox proportional hazard mode analysis. To the best of our knowledge, this is the first study to have demonstrated the predictive values for peritoneal recurrence and poor prognosis of CD44 mRNA in peritoneal washes in gastric cancer patients with stage II. As to the reason for the different properties of free cancer cells in stage II, we speculate that $\mathrm{CD} 44^{+}$cells may be more aggressive than $\mathrm{CEA}^{+}$cells and a small number of CD44 cells may be associated with the peritoneal recurrence in patients with stage II. However, further study is necessary in order to investigate this in detail.

In conclusion, our results demonstrated that CD44 mRNA, which is known as a cancer stem-like cell marker, may be a useful biomarker for the selection of high-risk patients in stage II gastric cancer patients who are in need of adjuvant chemotherapy. A further large-scale study is needed in order to validate our findings.

\section{Acknowledgements}

We thank Ms. J. Tamura for her excellent technical support. We thank to all members of the upper gastroenterological group for sampling of clinical specimens. This study was supported by a Grant-in-Aid for Scientific Research (C; 21591734).

\section{References}

1. Yamazaki H, Oshima A, Murakami R, Endoh S and Ubukata T: A long-term follow-up study of patients with gastric cancer detected by mass screening. Cancer 63: 613-617, 1989.

2. Katai H, Maruyama K, Sasako M, Sano T, Okajima K, Kinoshita T and Naparkov A: Mode of recurrence after gastric cancer surgery. Dig Surg 11: 99-103, 1994.

3. Yoo CH, Noh SH, Shin DW, Choi SH and Min JS: Recurrence following curative resection for gastric carcinoma. BR J Surg 2: 244-249, 1998.

4. Lowe E and Mcennea H: Peritoneal washing cytology: a retrospective analysis of 175 gynaecological patients. Aust N Z J Obstet Gynaecol 29: 55-61, 1989.

5. Bounenkamp JJ, Songun I, Hermans J and van de Velde CJH: Prognostic value of positive cytology findings from abdominal washings in patients with gastric cancer. Br J Surg 83: 672-674, 1996.

6. Hayes N, Wayaman J, Wadehara V, Scott DJ, Raimes SA and Griffin SM: Peritoneal cytology in the surgical evaluation of gastoric carcinoma. Br J Cancer 79: 520-524, 1991.

7. Sobin LH, Gospodarowics MK and Wittekind CH: TNM classification of malignant tumors. 7th edition. John Wiley \& Sons, New York, 2009.

8. Japanese Gastric Cancer Association: Japanese Classification of Gastric Carcinoma. 14th edition, 2010.

9. Abe S, Yoshiwara H, Tabata H, Tachibana M, Monden N, Nakamura $T$ and Nagaoka S: Curative resection of gastric cancer: limitation of peritoneal lavage cytolology in predicating the outcome. J Surg Oncol 59: 226-229, 1995.

10. Nakanishi H, Kodera Y, Yamamura Y, Ito S, Kato T, Ezaki T and Tatematsu M: Rapid quantitative detection of carcinoembryonic antigen-expressing free tumor cells in the peritoneal cavity of gastric-cancer patients with real-time RT-PCR on the lightcycler. Int J Oncol 89: 411-417, 2000.

11. Kodera Y, Nakanishi H, Ito S, Yamamura Y, Kanemitsu Y, Simizu Y, Hirai T, Yasui K, Kato T and Tatematsu M: Quantitative detection of disseminated free cancer cells in peritoneal washes with real-time reverse transcriptasepolymerase chain reaction. Ann Surg 235: 499-506, 2002.

12. Iinuma H, Okinaga K, Egami H, Mimori K, Hayashi N, Nishida K, Adachi M, Mori M and Sasako M: Usefulness and clinical significance of quantitative real-time RT-PCR to detect isolated tumor cells in the peritoneal blood and tumor drainage blood of patients with colorectal cancer. Int J Oncol 28: 297-306, 2006.

13. Tamura $\mathrm{N}$, Iinuma $\mathrm{H}$ and Takada $\mathrm{T}$ : Prospective study of quantitative CEA and CK20 mRNA detection in peritoneal washes to predict peritoneal recurrence in gastric carcinoma patients. Oncol Rep 17: 667-672, 2007.

14. O'Brien CA, Pollett A, Gallinger S and Dick JE: A human colon cancer cell capable of initiating tumour growth in immunodeficient mice. Nature 445: 106-110, 2007.

15. Ricci-Vitiani L, Lombardi DG, Pilozzi E, Biffoni M, Todaro M, Peschle $\mathrm{C}$ and Maria RD: Identification and expansion of human colon-cancer-initiating cells. Nature 445: 111-115, 2007.

16. Singh SK, Clarke ID, Terasaki M, et al: Identification of a cancer stem cell in human brain tumors. Cancer Res 63: 5821-5828, 2003.

17. Ieta K, Tanaka F, Haraguchi N, et al: Biologial and genetic characteristics of tumor-initiating cells in colon cancer. Ann Surg Oncol 15: 638-648, 2007.

18. Singh SK, Hawkins C, Clarke ID, Squire JA, Bayani J, Hide T, Henkelman RM, Cusimano MD and Dirks PB: Identification of human brain tumour initiating cells. Nature 432: 396-401, 2004. 
19. Al-Haji M, Wicha MS, Benito-Hernandez A, Morrison SJ and Clarke MF: Prospective identification of tumorigenic breast cancer cells. Proc Natl Acad Sci USA 100: 3983-3988, 2003.

20. Li C, Heidt DG, Dalerba P, Burant CF, Zhang L, Adsay V, Wicha M, Clarke MF and Simeone DM: Identification of pancreatic cancer stem cells. Cancer Res 67: 1030-1037, 2007.

21. Dalerba P, Dylla SJ, Park IK, Liu R, Wang X, Cho RW, Hoey T, Gurney A, Huang EH, Simeone DM, Shelton AA, Parmiani G, Castelli $\mathrm{C}$ and Clarke MF: Phenotypic characterization of human colorectal cancer stem cells. Proc Natl Acad Sci USA 104: 10158-10163, 2007.

22. Hermann PC, Huber SL, Herrler T, Aicher A, Ellwart JW, Guba M, Bruns CJ and Heeschen C: Distinct populations of cancer stem cells determine tumor growth and metastatic activity in human pancreatic cancer. Cell Stem Cell 1: 313-323, 2007.

23. Takaishi S, Okumura T, Tu S, Wang SS, Shibata W, Vigneshwaran R, Gordon SA, Shimada Y and Wang TC: Identification of gastric cancer stem cells using the cell surface marker CD44. Stem Cells 27: 1006-1020, 2009.

24. Du L, Wang H, He L, Zhang J, Ni B, Wang X, Jin H, Cahuzac N, Mehrpour M, Lu Y and Chen Q: CD44 is of functional importance for colorectal cancer stem cells. Clin Cancer Res 14: 6751-6760, 2008.

25. Iinuma H, Okinaga $\mathrm{K}$, Adachi $\mathrm{M}$, et al: Detection of tumor cells in blood using CD 45 magnetic cell separation followed by nested mutant allele-specific amplification of p53 and K-ras genes in patients with colorectal cancer. Int J Cancer 89: 337-344, 2000.
26. Kruger W, Togel F, Rossing S, Kroger N and Zander AR: Improvement of breast cancer cell detection by immunomagnetic enrichment. Cytometry 1: 135-139, 1999.

27. Wielenga VJ, Smits R, Korinek V, Smit L, Kielman M, Fodde R, Clevers H and Pals ST: Expression of CD44 in Apc and Tcf mutant mice implies regulation by the WNT pathway. Am J Pathol 154: 515-523, 1999 .

28. Cristofanilli M, Budd T, Ellis MJ, et al: Circulating tumor cells, disease progression and survival in metastatic breast cancer. $\mathrm{N}$ Engl J Med 351: 781-791, 2004.

29. Cohen SJ, Punt CJA, Iannotti N, et al: Relationship of circulating tumor cells to tumor response, progression-free survival, and overall survival in patients with metastatic colorectal cancer. J Clin Oncol 6: 3213-3221, 2008.

30. Oyama K, Terashima M, Takagane A and Maesawa C: Prognostic significance of peritoneal minimal residual disease in gastric cancer detected by reverse transcription-polymerase chain reaction. Br J Surg 91: 435-443, 2004.

31. Ito S, Nakanishi H, Kodera Y, Mochizuki Y, Tatematsu M and Yamamura Y: Prospective validation of quantitative CEA mRNA detection in peritoneal washes in gastric carcinoma patients. Br J Cancer 93: 986-992, 2005. 